\title{
Assets Measurement Principles According to Croatian and Polish Accounting Standards
}

\section{Ivana Mamić Sačer}

Faculty of Economics and Business, University of Zagreb, Croatia imamic@efzg.hr

\section{Beata Zyznarska-Dworczak}

Poznan University of Economics and Business, Department of Accounting and Financial Audit, Poznan, Poland

b.zyznarska-dworczak@ue.poznan.pl
CroEconsur

Vol. 22

No. 1

June 2020

pp. 41-64

Received: January 21, 2020

Accepted: April 16, 2020

Review Article

doi:10.15179/ces.22.1.2

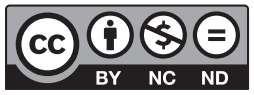

\section{Abstract}

There are many kinds of international operations, and entities from different countries can operate in different regulatory frameworks. This is why comparative international accounting has become more and more important. There are great efforts made by the EU, the IASB, the FASB, and other institutions in order to achieve comparable financial statements. Still, there are many accounting differences among the countries. The EU member states are restricted by the European Regulation on the application of the IFRS but the regulation of accounting principles for micro, small, and medium sized entities represents the national regulators' choice. The main goal of the paper is to provide a description of the existing accounting framework and the standard setting process in two European countries: Croatia and Poland. Research methodology is based on a 
critical analysis of scholarly literature and the comparison of Polish and Croatian Accounting Acts, Polish Accounting Standards and Croatian Financial Reporting Standards, in terms of main accounting principles for assets. The authors test the thesis that the national accounting standard setting process affects the form and content of accounting principles and standards. Therefore, the research focus is related to several accounting areas and the paper investigates accounting principles for different kinds of assets.

Keywords: accounting principles, accounting standards, financial reporting standards, Croatia, Poland

JEL classification: F23, G38, M41, M48

\section{Introduction}

Accounting information plays a key role in the business world since the business decision making process depends on accounting information. The owners of micro and small entities often consider the accounting function only as an operating cost. However, large entities are aware of the importance of accounting and financial reporting. Today, there are no limits for business operation. International operation plays a great part in economy. So, accounting faces challenges in terms of being able to provide the support for such economy in the form of its reports, statements, and other useful information. One of the presumptions for this support is comparable accounting information.

Although there are great efforts made by the European Union, the International Accounting Standards Board, the Federal Accounting Standards Board, and other institutions in order to achieve comparable financial statements, there are still many accounting differences among the countries. Those efforts to improve comparability usually concern companies that operate on financial markets. On the other hand, micro, small, and medium sized companies that are not a part of financial markets usually follow the accounting principles requested by national 
regulatory institutions. Accounting principles play an inevitable role for the business world. They have an impact on financial reporting and consequently they influence different users of financial statements. The basic accounting principles in the European Union are set by the European Accounting Directive (No. 2013/34/EU) and the International Financial Reporting Standards (IFRS). The European Union member states are restricted by the European Regulation on the application of the IFRS but the regulation of accounting principles for micro, small, and medium sized entities represents the national regulators' choice. Diverse practice in this field is recognized in Croatia and Poland.

The main goal of the paper is to provide a description of the existing accounting framework and the standard setting process in two European countries: Croatia and Poland. Other than that, our aim is to compare the Croatian Financial Reporting Standards (CFRS) and the accounting standards in force in Poland (ASP). The research focus is related to several accounting areas and the paper investigates accounting principles for intangible assets, property, plant and equipment, investment property, biological assets, non-current assets held for sale, and inventory. The results of the conducted comparative analysis apply for three different sets of accounting standards (IFRS, CFRS, and ASP).

\section{Significance of Harmonization and Standardization in Accounting}

Accounting is subject to continuous evolutionary processes. For years, its development has stimulated economic development as well as social and environmental development. In recent decades, the process of accounting evolution has gained a more dynamic pace. The process was mainly influenced by globalization, increased competitiveness and its internationalization, technological progress, as well as enterprises' actions focused on sustainable development (Zyznarska-Dworczak, 2019). One of the purposes of international accounting research is to make apparent in different countries the connection between 
accounting institutions and practices and their environment. Such research observes accounting profiles in similar or different settings and situations in order to demonstrate logical connections (Gernon \& Wallace, 1995). Contemporary accounting in any country is not the outcome of invention within a single country or culture but rather the outcome of innovations in many places across centuries. International accounting aims to situate local accounting practices of today within a comparative framework across space (Carnegie \& Napier, 2002). In order to achieve a greater understanding of why international differences exist, it is necessary to have an awareness of the comparative influences which affect the development of reporting requirements and practices (Gray, Campbell, \& Shaw, 1984). After all, accounting is seen as a technical craft which provides a neutral and unbiased set of corporate financial data (Saudagaran \& Diga, 1999).

The development of accounting from a comparative international perspective is driven by globalization processes. Currently, there is a large movement toward international comparability and harmonization of national accounting standards through the adoption of IFRS (Judge, Li, \& Pinsker, 2010). On the other hand, there are certain specifics of every country that need to be implemented in the regulations and accounting standards. As a result, a certain confrontation between opposite requirements is present. It is the national regulator's responsibility to decide and introduce the most appropriate solution in the form of national accounting rules.

There are some problems that go in line with accounting diversity. In that context, Beke (2010) indicates problems with the preparation of consolidated financial statements, access to foreign capital markets, the comparability of financial statements, and lack of high-quality accounting information. Further, with the growing internationalization of economic trade and the globalization of businesses and financial markets, financial information prepared according to national accounting system may no longer satisfy the needs of users whose decisions are more and more international in scope. In some ways, purely domestic information may even be a handicap for businesses as well as investors (Zeghal \& 
Mhedhbi, 2006). In that sense, harmonization, convergence, and standardization issues are raised.

Harmonization is defined as "a process of increasing the compatibility of accounting practices by setting bounds to their degree of variation while standardization appears to imply the imposition of a more rigid and narrow set of rules" (Nobes \& Parker, 2008, p. 75). The objective of accounting harmonization is to have comparable financial statements from companies in different countries (Doupnik \& Perera, 2007). Furthermore, according to Doupnik and Perera (2007), the harmonization of regulations (de jure harmonization) does not necessarily produce the harmonization of practices (de facto harmonization).

Rezaee, Smith, and Szendi (2010) define convergence as a process of the gradual elimination of differences between the IFRS and the United States' generally accepted accounting principles (US GAAP). In their research, they presume that the convergence process involves changes in both the US GAAP and the IFRS to eliminate differences (Rezaee et al., 2010). However, convergence can be observed for every national accounting standard in comparison to the IFRS.

Standardization is a stronger way of unifying accounting systems because it eliminates alternatives in accounting practices where only the suggested alternatives implemented in the standards can be selected by the companies.

For the purposes of accounting harmonization, there are several possible instruments that can be used. When it comes to the European Union, the most significant instrument is the EU Accounting Directive. Other than that, there are two sets of standards with the largest group of users: the IFRS and the US GAAP that directly or indirectly can influence national accounting practices. It is important to mention a lot of guidance, decisions, and other information regarding accounting issued by the OECD, the World Bank, or specially requested information by national financial markets. Since these institutions request certain information for their purposes, their influence on the accounting harmonization 
is inevitable. National statistic institutions can also have an important role in defining what will be regulated by the national regulatory body.

There are two levels of accounting standardization: primary and secondary (Žager, Mamić Sačer, Sever Mališ, Ježovita, \& Žager, 2017). The first level of standardization includes national instruments for unifying accounting principles. These instruments are national accounting standards and/or national generally accepted accounting principles. Such instruments are used in order to have a direct influence on the accounting principles that a certain entity can choose for its accounting policy. On the second level, there are some other instruments that can directly or indirectly impact the way accounting is done. Such instruments are the US generally accepted accounting principles, the International Financial Reporting Standards, and national accounting standards of other countries. The IFRS and the US GAAP are usually used as the best practice and often serve as a role model for forming national accounting standards/principles. For the companies that try to quote on foreign financial markets, sometimes foreign national accounting standards should be applied too.

There are different possibilities to oblige companies to implement a certain set of accounting principles. These options are (Dečman et al., 2013):

- National accounting standards for micro entities,

- National accounting standards (for small and medium sized entities),

- National generally accepted accounting principles,

- International financial reporting standards for small and medium sized entities,

- International financial reporting standards,

- SMEs use the IFRS with the exemption of selected standards,

- SMEs use only defined IFRSs,

- Some combination of the abovementioned options. 
Accounting standardization may be perceived not only as an economic logic, but also from the perspective of legitimacy theory and institutional theory. On the one hand, these positive theories assume that companies operate under a "social contract" focused on winning social acceptance, and retaining it by international accounting standard adoption (Zyznarska-Dworczak, 2018). On the other hand, accounting standardization may be perceived as the effect of all three forms of isomorphic pressures (coercive, mimetic, and normative) (e.g., Judge et al., 2010; Rodrigues \& Craig, 2007; Zehri \& Chouaibi, 2013).

Based on the noticed general harmonization and standardization processes in accounting, four research questions are set:

Q1: Are national accounting standard setting processes in Croatia and Poland closely related to the international harmonization processes?

Q2: Do Croatian and Polish accounting legislations simplify financial reporting for micro entities according to the EU Accounting Directive?

Q3: Are the form and the content of national accounting principles and standards in Croatia and Poland equal?

Q4: Are assets measurement principles according to the Croatian and Polish accounting standards similar?

An attempt to answer these questions is presented in the following parts of this paper.

\section{Comparative Analysis of Croatian and Polish Accounting Standards for Assets}

\subsection{National Accounting Standard Setting Processes in Croatia and Poland}

Harmonization processes regarding the International Financial Reporting Standards are reflected in national accounting standards. This is why our research 
is focused on the national accounting standard setting process in Croatia and Poland. The aim was to explore whether the international harmonization processes are extended to national accounting standards in the observed countries. In order to explore this, the authors analyzed:

- the processes of setting national accounting standards,

- the work of national standard setters, and

- the form and the content of those standards.

National accounting standards in Croatia are called the Croatian Financial Reporting Standards and they were introduced in 2007. The Committee for Financial Reporting Standards plays the role of the national standard setter. The standard setting process for the CFRS is initiated by the Committee.

Table 1: Activities of Croatian and Polish Accounting Standard Setters

\begin{tabular}{|c|c|c|}
\hline & $\begin{array}{l}\text { Croatian Committee for Financial } \\
\text { Reporting Standards }\end{array}$ & $\begin{array}{l}\text { Polish Accounting Standards } \\
\text { Committee }\end{array}$ \\
\hline Financing & State budget & State budget \\
\hline Members & 9 & 16 \\
\hline Mandate & 5 years & 2 years \\
\hline Activities & $\begin{array}{l}\text { - To pass CFRS } \\
\text { - To prepare and publish CFRS in the } \\
\text { Official Gazette } \\
\text { - To pass interpretations on CFRS } \\
\text { - To propose the form and content of } \\
\text { annual financial statements to the } \\
\text { Minister of Finance } \\
\text { - To provide an opinion on the suggested } \\
\text { European Union legislative acts and } \\
\text { other accounting issues at the request of } \\
\text { the Ministry of Finance } \\
\text { - To analyze and monitor accounting } \\
\text { theory and practice } \\
\text { - To report annually about its work to the } \\
\text { Croatian Government. }\end{array}$ & $\begin{array}{l}\text { To issue national accounting standards, } \\
\text { and to review and update existing } \\
\text { standards } \\
\text { - To issue opinions on draft legal acts in } \\
\text { the scope of economic activity } \\
\text { - To analyze International Accounting } \\
\text { Standards } \\
\text { - To analyze accounting standards } \\
\text { developed by other countries as well as } \\
\text { European Union directives - in the field } \\
\text { of accounting } \\
\text { - To cooperate with international } \\
\text { organizations for accounting } \\
\text { standardization. }\end{array}$ \\
\hline
\end{tabular}

Sources: Law on Accounting (Zakon o računovodstvu, Narodne novine 78/2015, 134/2015, 120/2016, 116/2018); Rule on Croatian Committee for Financial Reporting Standards' Activity (Pravilnik o načinu rada Odbora za standarde financijskog izvještavanja, Narodne novine 1/2016); Regulation of the Minister of Finance of November 28, 2001 on the scope of operation and organization of the Accounting Standards Committee, Journal of Laws of 2001, No. 140, Item 1580 . 
Before 2006, Croatian companies were supposed to apply the IFRS. Since the majority of Croatian economy consists of SMEs, for which the application of the IFRS represented an administrative and financial burden, the Law on Accounting gave the right to the Committee for Financial Reporting Standards to prepare national accounting standards for SMEs. The content and the structure of the standards prepared by the Committee were subsequently changed due to the requests of the European Commission during Croatia's accession to the EU (OSFI, 2008). The standards should have been in line with the First, Fourth, and Seventh EU Directive and with Regulation 1606/2002. The newly formed standards entered into force on January 1, 2008. In the twelve-year period of the CFRS existence, the standards have been changed. The main reasons for these changes have been changes to the EU Accounting Directive, changes to the Law on Accounting, and modifications and amendments to the IFRS.

The ongoing process of adjusting Polish legislation to international accounting regulations has been carried out for years. It can be also observed that both national and international provisions are subject to constant changes. Nevertheless, there are still differences between those regulations, which cause relevant values to be differently presented in financial statements (Chochorek, 2016). The Polish accounting system is basically regulated by the Accounting Act of September 29, Journal of Laws of 1994, No. 121, Item 591 (the Polish Accounting Act). This act regulates who is obligated to use the IFRS and in what situations national accounting standards may be applied. The Accounting Act permits or requires certain Polish entities to apply the IFRS as adopted by the EU as their primary basis accounting principles (see Table 2). 
Table 2: Guidelines for the Application of IFRS in Poland According to the Polish Accounting Act

\begin{tabular}{l|l|l}
\hline \multicolumn{1}{c|}{ Entities } & $\begin{array}{c}\text { Standalone } \\
\text { financial } \\
\text { statements }\end{array}$ & $\begin{array}{c}\text { Consolidated } \\
\text { financial } \\
\text { statements }\end{array}$ \\
\hline $\begin{array}{l}\text { Entities listed on a regulated market in Poland or other } \\
\text { European Economic Area (EEA) country }\end{array}$ & Optional & Required \\
\hline $\begin{array}{l}\text { Banks (other than those included in 1, 3, 4, and 5) } \\
\text { Entities that applied for permission to be listed on a regulated } \\
\text { market in Poland or other European Economic Area (EEA) } \\
\text { country }\end{array}$ & Optional & Optional \\
$\begin{array}{l}\text { Entities that are part of a group where the parent prepares } \\
\text { consolidated financial statements for statutory purposes in } \\
\text { accordance with IFRS as adopted by the EU }\end{array}$ & Optional & Optional \\
\hline $\begin{array}{l}\text { Branches of a foreign entrepreneurship that prepare separate } \\
\text { financial statements for statutory purposes in accordance with } \\
\text { IFRS as adopted by the EU }\end{array}$ & Optional & Not permitted \\
\hline \begin{tabular}{l} 
Other entities \\
\hline
\end{tabular}
\end{tabular}

Source: Own elaboration based on Polish Accounting Act (Art. 10); EY (2017, p. 138).

Under the Polish Accounting Act, the IFRS are mandatory for the preparation of consolidated financial statements of listed entities and banks. Listed entities and banks are permitted in some cases to use EU-endorsed IFRS for the preparation of their individual financial statements. Subsidiaries have the option to prepare these in accordance with EU-endorsed IFRS if the parent company prepares its financial statements using the same standards. Insurance companies are also required to prepare their individual and consolidated financial statements in accordance with the accounting requirements of the Accounting Act of 1994, as well as with relevant regulations of the Ministry of Finance (Regulation of the Minister of Finance of December 28, 2009 and Regulation of December 12, 2001). In most cases, insurance companies are also given the option to use EUendorsed IFRS.

Companies that do not apply the IFRS in the preparation of their financial statements are required to follow the accounting requirements included in the Accounting Act of 1994 and its by-laws. Polish basic accounting rules are determined in the Polish Accounting Act, and only in cases when certain issues are not covered by the Act, entities may apply the Domestic Accounting Standards 
issued by the Accounting Standards Committee. In the absence of relevant regulations in the Domestic Accounting Standards, the International Accounting Standards may be used (Zyznarska-Dworczak \& Mamić Sačer, 2019). Under the Accounting Act of 1994, the Accounting Standards Committee of the Ministry of Finance is responsible for setting the Domestic Accounting Standards in Poland (DASP), which provide guidance with respect to the preparation of financial statements.

A comparison of the normative system of the accounting framework in Poland and Croatia allows us to see similarities and differences. Answering the first research question of this paper, we agree that both national accounting standard setting processes - in Croatia and Poland - are closely related to the international harmonization processes. The manner of regulating accounting systems is substantially similar for both countries, as are the tasks of the national accounting standards committees; however, there remain differences in the scope of entities obliged to use the IFRS, as well as the methods of applying national accounting standards.

\subsection{Simplification of Financial Reporting for Micro Entities in Croatia and Poland}

The EU Accounting Directive (2013/34) was introduced in 2013 with a postponed date for bringing into force the selected alternatives from the Directive through the laws, regulations, and other administrative provisions of the $\mathrm{EU}$ member states. Significant effort was made through the EU Directive in order to simplify financial reporting for micro entities. Such simplifications include certain exemptions for micro entities from a general publication requirement as are described in Article 36 of the Directive. The reporting exemptions for micro entities in Croatia and Poland are presented in Table 3. 
Table 3: Reporting Exemptions for Micro Entities in Croatia and Poland

\begin{tabular}{|c|c|c|}
\hline $\begin{array}{l}\text { Exemptions according to the EU Directive } \\
\text { Article } 36\end{array}$ & $\begin{array}{c}\text { Croatian accounting } \\
\text { framework }\end{array}$ & $\begin{array}{c}\text { Polish accounting } \\
\text { framework }\end{array}$ \\
\hline $\begin{array}{l}\text { The obligation to present "Prepayments and accrued } \\
\text { income" and "Accruals and deferred income" }\end{array}$ & Not implemented & $\begin{array}{l}\text { Implemented (micro } \\
\text { companies may elect } \\
\text { not to recognize } \\
\text { deferred tax) }\end{array}$ \\
\hline $\begin{array}{l}\text { The obligation to draw up notes to the financial } \\
\text { statements in accordance with Article } 16 \text {, provided } \\
\text { that the information required by points (d) and } \\
\text { (e) of Article } 16(1) \text { of this Directive and by Article } \\
24(2) \text { of Directive } 2012 / 30 / E U \text { is disclosed at the } \\
\text { foot of the balance sheet }\end{array}$ & Not implemented & Implemented \\
\hline $\begin{array}{l}\text { The obligation to prepare a management report } \\
\text { in accordance with Chapter } 5 \text {, provided that the } \\
\text { information required by Article } 24(2) \text { of Directive } \\
2012 / 30 / E U \text { is disclosed in the notes to the financial } \\
\text { statements or, in accordance with point (b) of this } \\
\text { paragraph, at the foot of the balance sheet }\end{array}$ & $\begin{array}{l}\text { Implemented - micro } \\
\text { entities should publish } \\
\text { information on their } \\
\text { treasury stocks in the } \\
\text { notes to the financial } \\
\text { statements (Law on } \\
\text { Accounting, 2015) }\end{array}$ & Implemented \\
\hline $\begin{array}{l}\text { The obligation to publish annual financial } \\
\text { statements in accordance with Chapter } 7 \text { of } \\
\text { this Directive, provided that the balance sheet } \\
\text { information contained therein is duly filed, in } \\
\text { accordance with national law, with at least one } \\
\text { competent authority designated by the member state } \\
\text { concerned }\end{array}$ & Not implemented & Implemented \\
\hline $\begin{array}{l}\text { Permissions according to the EU Directive } \\
\text { Article } 36.2\end{array}$ & $\begin{array}{l}\text { Croatian accounting } \\
\text { framework }\end{array}$ & $\begin{array}{l}\text { Polish accounting } \\
\text { framework }\end{array}$ \\
\hline $\begin{array}{l}\text { To draw up only an abridged balance sheet showing } \\
\text { separately at least those items preceded by letters in } \\
\text { Annexes III or IV, where applicable }\end{array}$ & Not implemented & Implemented \\
\hline $\begin{array}{l}\text { To draw up only an abridged profit and loss account } \\
\text { showing separately at least the prescribed items from } \\
\text { Article 36.2.b, where applicable }\end{array}$ & Not implemented & Implemented \\
\hline
\end{tabular}

Source: Own elaboration based on Law on Accounting (Zakon o računovodstvu, Narodne novine 78/2015, 134/2015, 120/2016, 116/2018) and Accounting Act of September 29, 1994 (consolidated text: Journal of Laws of 1994, No. 121, Item 591, last amendment: Journal of Laws of 2019, Item 351).

Although one of the reasons for changing the Fourth EU Directive was to simplify accounting requirements for micro entities, our research results show that such a possibility was not introduced in the Croatian accounting framework, but we can see some exemptions and simplifications in the field of accounting and financial reporting offered in the Polish Accounting Act for micro companies. 


\subsection{The Structure of Accounting Standards}

Since accounting standards represent more detailed accounting principles, every group of accounting standards has its own structure. Usually, accounting standards have some framework for the application of the standards as well as their interpretations (e.g., IFRS). Further, some national accounting standards are structured according to the main categories from the financial statements, e.g., IFRS or Slovenian Accounting Standards (Slovenski inštitut za revizijo, 2016). In some cases, there are accounting standards dedicated to certain topics, financial statements, or other reports. For instance, IAS 41 - Agriculture, or German Accounting Standard 21 - Cash flow statement, Slovenian Accounting Standard 24 - Formats of income statement for external business reporting, or Slovenian Accounting Standard 33 - Accounting solutions in associations and disability organizations (Slovenski inštitut za revizijo, 2016; DRSC, 2019). Usually, accounting standards are a set of standards for external financial reporting. This is why the example of Slovenian Accounting Standards is interesting, as they prescribe not only the standards for external financial reporting, but also for internal reporting (e.g., SAS 16 - Cost classification by types, centers and units). Other than that, the Slovenian Accounting Standards include a standard for nonprofit organizations (SAS 36 - Accounting solutions in non-profit organizations - private-law entities).

Croatian Financial Reporting Standards are formed following the main categories from the financial statements, added with some special topics, as for instance Financial statements, Consolidated financial statements, Agriculture, etc. (Table 4). Also, the Committee for Financial Reporting Standards set the framework for the application of CFRS. Although the Committee discusses topics beyond the CFRS, such as non-financial reporting or the Law on Auditing, the CFRS are externally oriented accounting standards and are not applicable only for the non-profit sector. On the other hand, the Polish accounting system, as mentioned above, is regulated mainly by the Polish Accounting Act, and only in cases when 
certain issues are not covered by the Act, the Domestic Accounting Standards are used. Until now, the Accounting Standards Committee has issued 13 standards.

The content of individual accounting standards according to the Croatian and Polish frameworks follows a common order: introduction, definition, content, recognition, measurement, disclosure, and effective date. The names of national standards of accounting in Poland and Croatia are presented in Table 4.

Table 4: The Structure of CFRS and Domestic Accounting Standards in Poland

\begin{tabular}{|c|c|}
\hline Croatian Financial Reporting Standards & Domestic Accounting Standards in Poland \\
\hline $\begin{array}{l}\text { CFRS } 1 \text { Financial statements } \\
\text { CFRS } 2 \text { Consolidated financial statements } \\
\text { CFRS } 3 \text { Accounting policies, changes in } \\
\text { accounting estimates and errors } \\
\text { CFRS } 4 \text { Events after the reporting period } \\
\text { CFRS } 5 \text { Long-term intangible assets } \\
\text { CFRS } 6 \text { Long-term tangible assets } \\
\text { CFRS } 7 \text { Investment property } \\
\text { CFRS } 8 \text { Non-current assets held for sale and } \\
\text { discontinued operations } \\
\text { CFRS } 9 \text { Financial assets } \\
\text { CFRS } 10 \text { Inventories } \\
\text { CFRS } 11 \text { Receivables } \\
\text { CFRS } 12 \text { Equity } \\
\text { CFRS } 13 \text { Liabilities } \\
\text { CFRS } 14 \text { Accruals } \\
\text { CFRS } 15 \text { Revenues } \\
\text { CFRS } 16 \text { Expenditures } \\
\text { CFRS } 17 \text { Agriculture }\end{array}$ & $\begin{array}{l}\text { DASP } 1 \text { Cash flow } \\
\text { DASP } 2 \text { Income taxes } \\
\text { DASP } 3 \text { Unfinished building services } \\
\text { DASP } 4 \text { Impairment of assets } \\
\text { DASP } 5 \text { Leasing, rental and tenancy } \\
\text { DASP } 6 \text { Provisions, accrued expenses, contingent } \\
\text { liabilities } \\
\text { DASP } 7 \text { Changes in accounting principles } \\
\text { (policy), estimation of values, correction } \\
\quad \text { of errors, events after the balance sheet } \\
\quad \text { date - booking and presentation } \\
\text { DASP } 8 \text { Real estate activity } \\
\text { DASP } 9 \text { Management commentary } \\
\text { DASP } 10 \text { Public-private partnership agreements } \\
\text { DASP } 11 \text { Fixed assets } \\
\text { DASP } 12 \text { Agriculture } \\
\text { DASP } 13 \text { Manufacturing cost as the basis for the } \\
\quad \text { valuation of products }\end{array}$ \\
\hline
\end{tabular}

Sources: Croatian Financial Reporting Standards (2015), Narodne novine 85/2015; Domestic Accounting Standards in Poland (DASP).

Table 4 confirms that in the selected issues, requiring more detailed solutions, both countries have prepared similar specific regulations, like agriculture (CFRS 17 and DASP 12) or accounting policies (CFRS 3 and DASP 7), but also have some different categories. The Croatian standards include more general issues, like financial statements, long-term tangible and intangible assets, investment property, financial assets, inventories, receivables, equity, liabilities, accruals, revenues, expenditures. In Poland, such categories are regulated in the Accounting Act, while the Domestic Accounting Standards in Poland specify more detailed valuation and presentation issues in the fields f.e. cash flow, income taxes, leasing, 
rental and tenancy, real estate activity, management commentary, manufacturing cost as the basis for the valuation of products. Based on the abovementioned results, we can answer the third research question. The form and the content of national accounting principles and standards are not quite equal for the analyzed countries.

\subsection{Accounting Principles for Assets Recognition and Measurement Regulated by the Croatian and Polish Accounting Standards}

The fourth research question was: Are assets measurement principles according to the Croatian and Polish accounting standards similar? In order to argue this question, an analysis of the Croatian and Polish accounting standards was done.

For an item to be recognized as an asset, it needs to meet certain criteria defined through standards. Items that do not meet such criteria are not allowed to be recognized in financial statements and this is why such items do not influence the financial position and business performance of an entity. According to the IFRS, an asset is "a present economic resource controlled by the entity as a result of past events. An economic resource is a right that has the potential to produce economic benefits" (IASB, 2018, p. 28). According to the CFRS, an asset is a resource controlled by an entity as a result of past events from which future economic benefits are expected to flow to the entity. The definition is in line with the IFRS definition of assets.

To be recognized in financial statements, an item should meet two recognition criteria: "it is probable that any future economic benefit associated with the item will flow to or from the entity, the item has a cost or value that can be measured with reliability" (Croatian Financial Reporting Standards, 2015, p. 6).

Table 5 presents a comparison of selected accounting principles from IFRS, ASP, and CFRS. For the purpose of the research, we selected the standards that deal 
with intangible and tangible assets. First, we presented the IFRS requirements from the following IFRS standards: IAS 38, IAS 36, IFRS 3, IAS 16, IAS 40, IAS 41, IFRS 5, and IAS 2. Then, the appropriate standards from CFRS (CFRS 5, 6, 7, 8, 10, and 17) and Accounting Standards in Poland (according to the Polish Accounting Act) were found, analyzed, and compared. The research results indicate that there are almost identical sentences regarding the financial reporting requirements used in the observed IFRSs and CFRSs, whereas such similarity is not found in the case of Polish Accounting Standards. Further, there are some differences in the accounting principles for recognition and measurement of the selected assets:

- Intangible assets: There are two methods for intangible assets subsequent measurement: cost and revaluation method.

- Property, plant, and equipment: There are similar requirements in the accounting standards in the analyzed countries.

- Investment property: There are similar requirements in the accounting standards in the analyzed countries.

- Biological assets: There are similar requirements in the accounting standards in the analyzed countries.

- Non-current assets held for sale: Accounting Standards in Poland do not specify any requirements concerning the valuation of assets and disposal groups held for sale and do not require a separate presentation of such assets. Again, the IFRS and CFRS are very aligned for these assets.

- Inventory: IAS 2 and CFRS 10 prescribe the same techniques and methods for valuation of inventory. Besides FIFO and average weighted method, Accounting Standards in Poland include the LIFO method, as well. 
Table 5: Comparison of the IFRS application in Poland and Croatia

\begin{tabular}{c|c}
\hline Poland & Croatia \\
\hline Intangible assets (IAS 38, IAS 36, IFRS 3) \\
\hline
\end{tabular}

Article 3, Item 14 (Accounting Act)

Property rights acquired by the entity suitable for economic use, whose expected useful economic life exceeds one year, intended to be used for the entity's needs, in particular: author's property rights, related rights, licenses, concessions, or other.

There are two methods for intangible assets subsequent measurement: cost and revaluation method.

CFRS 5 Non-current intangible assets

To be recognized as intangible, an item should meet two recognition criteria: it is probable that the future economic benefits that are attributable to the asset will flow to the entity; and the cost of the asset can be measured reliably.

Initially, all intangibles (goodwill included) are measured at cost.

There are two categories of intangible assets: assets with indefinite and finite life.

There are two methods for intangible assets subsequent measurement: cost and revaluation method.

Intangibles with indefinite life should not be depreciated but should be tested on impairment.

Property, plant, and equipment (IAS 16)

The components of property, plant, and equipment are neither mentioned nor defined. Consequently, overhauls give rise to a provision accounted for on a cumulative basis.

Article 3, Item 15 (Accounting Act) defines "fixed assets" as property, plant, and equipment and assets equated with them, with an expected period of economic useful life longer than one year, complete, usable and intended for the needs of the unit. They include, in particular:

a) real estate - including land, perpetual usufruct right to land, and buildings, as well as separate premises owned by a cooperative, cooperative ownership right to a dwelling, and cooperative right to business premises,

b) machines, devices, means of transport, and other,

c) improvements in foreign fixed assets,

d) livestock.

Valuation at the end of the year (Article 28):

- according to the purchase prices or production costs, or revalued value (on the basis of separate regulations), less depreciation or redemption write-offs, as well as write-offs for permanent impairment.

\section{CFRS 6 Tangible assets}

The two recognition criteria for tangible assets are the same as for intangible assets in CFRS 5. Initially, these assets shall be measured at costs depending on the way they were acquired. The capitalization of borrowing costs is allowed in accordance with CFRS 15 Expenses (CFRS 6.23).

As for the subsequent measurement, the entity shall choose the cost model or the revaluation model.

Amortization methods should reflect the patterns of future economic benefits from the asset. Allowed amortization methods are straight-line method, the diminishing balance method, and the units of production method (CFRS 6.49). At the end of each reporting period, it is required from the entity to estimate whether there is any indication that an asset can be impaired.
Article 3, Item 17 (Accounting Act)

Including into investments, and consequently into tangible assets

Valuation at the end of the year (Article 28): - according to the principles applied to tangible and intangible assets or according to the market price or in a fairly determined fair value.

\section{Investment property (IAS 40)}

\section{CFRS 7 Investment property}

The two recognition criteria for investment property are the same as for intangible assets (CFRS 5).

Initially, these assets shall be measured at costs depending on the way they were acquired. Any transactional costs should be included in initial costs.

For subsequent measurement, the entity shall choose between fair value model and cost model. As for fair value model, any gains or losses occurred as a result of fair value changes should be recognized as income or expenses in the profit and loss account. 


\section{Biological assets (IAS 41)}

The three recognition criteria and valuation for biological assets are the same as defined in IAS 41.

\section{CFRS 17 Agriculture}

The three recognition criteria for biological assets are the same as defined in IAS 41.10.

In cases where fair value of biological assets can be measured initially or at each balance sheet date, it should be measured at fair value less point-of-sale costs (CFRS 17.9).

If fair value of biological assets cannot be measured reliably, biological assets shall be measured (initially and subsequently) at cost less accumulated depreciation and accumulated impairment losses as defined in CFRS 6 and CFRS 10.

\section{Non-current assets held for sale (IFRS 5)}

There is a lack of requirements concerning the valuation of assets and disposal groups held for sale.

Depreciation is required.

Separate presentation and specific disclosures are not required.
CFRS 8 Non-current assets held for sale and

discontinued operation

The entity shall measure a non-current asset (or disposal group) classified as held for sale at the lower of its carrying amount and fair value less costs to sell.

The entity shall recognize an impairment loss for any initial or subsequent write-down of the asset (or disposal group) to fair value less costs to sell, to the extent that it has not been recognized.

The entity shall recognize a gain for any subsequent increase in fair value less costs to sell. This gain should not be greater than previously recognized loss

The requirements for separate disclosure of such assets and liabilities are the same as defined in IFRS 5.38 .

\section{Inventory (IAS 2)}

Article 34 (Accounting Act)

Entities may assess the value of materials and goods at the purchase price if it does not distort the value of assets, or on the basis of the acquisition price or manufacturing cost. The following methods can be applied: FIFO, LIFO, average weighted.
CFRS 10 Inventory

Inventories shall be measured at the lower of cost and net realizable value.

The cost of inventories shall comprise all costs of purchase, costs of conversion, and other costs incurred in bringing the inventories to their present location and condition.

CFRS allow the usage of specific identification method, FIFO, and weighted average cost method, but also standard cost method and retail method.

Sources: Own elaboration based on Domestic Accounting Standards in Poland (DASP), Chochorek (2016), EY (2017, pp. 155-159), and Croatian Financial Reporting Standards (2015), Narodne novine 85/2015; International Financial Reporting Standards (IASB, 2018).

Summarizing, valuation and measurement principles according to the Croatian and Polish accounting standards are in general rather similar, although at a different level some parts are detailed and clarified. The differences in the interpretation of 
certain categories may result in a different method of their valuation in accounting books and their presentation in the financial statements.

\section{Conclusion}

Accounting principles play an inevitable role for the business world. Since many companies operate globally, the accounting principles that they apply can influence their financial statements. However, the users of such statements expect their comparability. The issue of comparability improvement usually concerns those companies that operate on financial markets. On the other hand, micro, small, and medium sized companies that are not a part of financial markets usually follow the accounting principles requested by national regulatory institutions.

The intention of the paper was to analyze the similarities and differences between the Croatian and Polish accounting systems. The research methodology is based on a critical analysis of scholarly literature and the comparison of accounting standards (in particular, Polish and Croatian Accounting Acts, Polish Accounting Standards and Croatian Financial Reporting Standards) in terms of main accounting principles for certain areas prescribed by these accounting standards. The references on the topic of international accounting for the purpose of identifying similarities and differences in accounting systems (Choi \& Meek, 2008; Gibson, 2013; Nobes \& Parker, 2008; Radebaugh, Gray, \& Black, 2006; Grabinski, Kedzior, \& Krasodomska, 2014; Zehri \& Chouaibi, 2013; ZyznarskaDworczak \& Mamić Sačer, 2019; and others) are used as the theoretical base for the study. Furthermore, publicly available national financial reporting and accounting standards in Croatia and Poland are used for conducting our research.

The research results point to similarities in main areas of accounting standards in Croatia and Poland. Different approaches in the regulation of accounting treatment of certain areas are pointed out, as well. Both Croatia and Poland are in the process of implementing International Financial Reporting Standards. It is one of the key factors in the development of accounting standardization in the 
analyzed countries, which has resulted in the unification of regulations in both European Union countries.

After testing our first research question, we can agree that national accounting standard setting processes in Croatia and Poland are closely related to the international harmonization processes. Further, regarding our second question, research results indicate that the proposed simplification for micro entities offered by the EU Accounting Directive (2013/34) have not been introduced in Croatian accounting legislation. However, some exemptions and simplifications in the field of accounting and financial reporting are offered in the Polish Accounting Act for micro companies. In addition, our analysis has shown that the form and the content of national accounting principles and standards are not quite equal for the analyzed countries (the third research question). As the fourth research question was argued in the paper, it could be concluded that the valuation and measurement principles presented in Croatian and Polish accounting standards are in general rather similar. However, national accounting principles and standards in Croatia and Poland are not equal. The noticed differences between the countries could have special meaning for investors, but also for regulators, the European Union, and scientists with research aims in international accounting. The need for deepened research in the field of international comparative accounting is recognized, because different interpretations of balance sheet items and/or income and cost categories may result in various methods of their valuation in accounting books and their presentation in financial statements. 


\section{Literature}

Accounting Act of September 29, 1994. Consolidated text: Journal of Laws of 1994, No. 121, Item 591, last amendment: Journal of Laws of 2019, Item 351.

Beke, J. (2010). International accounting harmonization: Evidence from Europe. International Business and Management, 1(1), 48-61.

Carnegie, G. D., \& Napier, C. J. (2002). Exploring comparative international accounting history. Accounting, Auditing \& Accountability Journal, 15(5), 689718. doi: https://doi.org/10.1108/09513570210448966

Chochorek, M. (2016). Differences between the Polish Accounting Act and International Accounting Standards (IAS). Finanse i Controlling, 47/2016.

Choi, F. D. S., \& Meek, G. K. (2008). International accounting. Upper Saddle River, NJ: Pearson Prentice Hall.

Croatian Financial Reporting Standards. (2015). Narodne novine, 85/2015.

Dečman, N., Mamić Sačer, I., Sever Mališ, S., Sever, I., Tušek, B., Žager, K., \& Žager, L. (2013). Harmonizacija i standardizacija financijskog izvještavanja malih i srednjih poduzeća. Zagreb: HZRFD.

Domestic Accounting Standards in Poland (DASP), based on Resolutions of Accounting Standards Committee in Official Journal of the Minister of Finance in the years 2014-2019. Retrieved from: https://www.gov.pl/web/finanse/krajowestandardy-rachunkowosci

Doupnik, T., \& Perera, H. B. (2007). International accounting [ $1^{\text {st }}$ edition]. Boston, MA: McGraw-Hill/Irwin.

DRSC. (2019). Standards, interpretations, implementation guidance. Retrieved from: https://www.drsc.de/en/pronouncements/

European Commission. (2013). European Accounting Directive No. 2013/34/ EU. 
EY. (2017). Accounting and auditing: Doing business in Poland. Retrieved from: http://www.ey.com/Publication/vwLUAssets/ey-doing-business-in-polandaccounting-and-auditing/\$FILE/ey-dbp-accounting-and-auditing.pdf

Gernon, H., \& Wallace, R. O. (1995). International accounting research: A review of its ecology, contending theories and methodologies. Journal of Accounting Literature, 14, 54-106.

Gibson, C. H. (2013). Financial statement analysis. Cengage Learning.

Grabinski, K., Kedzior, M., \& Krasodomska, J. (2014). The Polish accounting system and IFRS implementation process in the view of empirical research. Accounting and Management Information Systems, 13(2), 281-310.

Gray, S. J., Campbell, L. G., \& Shaw, J. C. (1984). Influences on accounting development. In S. J. Gray, L. G. Campbell, \& J. C. Shaw (Eds.), International financial reporting: A comparative international survey of accounting requirements and practices in 30 countries (pp. 11-28). Springer. doi: https://doi.org/10.1007/9781-349-07442-6_3

IASB. (2018). Conceptual framework for financial reporting. London: IFRS Foundation.

Judge, W., Li, S., \& Pinsker, R. (2010). National adoption of international accounting standards: An institutional perspective. Corporate Governance: An International Review, 18(3), 161-174. doi: https://doi.org/10.1111/j.14678683.2010.00798.x

Nobes, C., \& Parker, R. (2008). Comparative international accounting $\left[10^{\text {th }}\right.$ edition]. Prentice Hall.

OSFI. (2008). Izvješće o radu Odbora za standarde financijskog izvještavanja za 2007. godinu. Retrieved from: http://www.osfi.hr/Default.aspx?sid=97

Pravilnik o načinu rada Odbora za standarde financijskog izvještavanja. (2016). Narodne novine, 1/2016. 
Radebaugh, H. I., Gray, J. S., \& Black, L. E. (2006). International accounting and multinational enterprises [ $6^{\text {th }}$ edition]. Wiley.

Regulation of the Minister of Finance of November 28, 2001 on the scope of operation and organization of the Accounting Standards Committee. Journal of Laws of 2001, No. 140, Item 1580.

Rezaee, Z., Smith, L. M., \& Szendi, J. Z. (2010). Convergence in accounting standards: Insights from academicians and practitioners. Advances in Accounting, 26(1), 142-154. doi: https://doi.org/10.1016/j.adiac.2010.01.001

Rodrigues, L. L., \& Craig, R. (2007). Assessing international accounting harmonization using Hegelian dialectic, isomorphism and Foucault. Critical Perspectives on Accounting, 18(6), 739-757.

doi: https://doi.org/10.1016/j.cpa.2006.02.007

Saudagaran, S. M., \& Diga, J. G. (1999). Evaluation of the contingency-based approach in comparative international accounting: A case for alternative research paradigms. Journal of Accounting Literature, 18, 57-95.

Slovenski inštitut za revizijo. (2016). Slovenian accounting standards. Uradni list $R S$, št. 95/15, 74/16 - popr., 23/17, 57/18, 81/18.

Zakon o računovodstvu. (2015). Narodne novine, 78/2015, 134/2015, 120/2016, $116 / 2018$.

Zeghal, D., \& Mhedhbi, K. (2006). An analysis of the factors affecting the adoption of international accounting standards by developing countries. The International Journal of Accounting, 41(4), 373-386.

doi: https://doi.org/10.1016/j.intacc.2006.09.009

Zehri, F., \& Chouaibi, J. (2013). Adoption determinants of the International Accounting Standards IAS/IFRS by the developing countries. Journal of Economics Finance and Administrative Science, 18(35), 56-62.

doi: https://doi.org/10.1016/S2077-1886(13)70030-1

Zyznarska-Dworczak, B. (2018). Accounting theories towards non-financial reporting. Studia Ekonomiczne, 356, 157-169. 
Zyznarska-Dworczak, B. (2019). Rachunkowość w ujęciu kognitywno-teoretycznym. Poznań: Wydawnictwo Uniwersytetu Ekonomicznego w Poznaniu.

Zyznarska-Dworczak, B., \& Mamić Sačer, I. (2019). Accounting systems in Croatia and Poland - comparative study. Zagreb International Review of Economics \& Business, 22(1), 55-72. doi: https://doi.org/10.2478/zireb-2019-0012

Žager, K., Mamić Sačer, S., Sever Mališ, S., Ježovita, A., \& Žager, L. (2017). Analiza financijskih izvještaja, načela - postupci - slučajevi, treće izmijenjeno i dopunjeno izdanje. Zagreb: Hrvatska zajednica računovođa i financijskih djelatnika. 